\title{
Dynamic Vulnerability: Application to the Bou-Areg Aquifer (Morocco)
}

\author{
Rachid Bouchnan ${ }^{1}$, Mina Amharref ${ }^{2}$, Abdes Samed Bernoussi ${ }^{3}$ \\ 1, 2 and 3 (Department of Earth Sciences, Geoinformation and Land Management Team (GAT) \\ Faculty of Science and Technology, Morocco)
}

\begin{abstract}
The combined effect between climate change and anthropogenic pressures on groundwater resources is reflected in the qualitative and quantitative degradation of these strategic reserves. This effect could reflect a change in vulnerability to pollution. In fact, the vulnerability is assessed on the basis of parameters that can vary in time such as recharge and depth. Through an application of the DRASTIC method on the Bou-Areg aquifer for the years 1969, 2000 and 2006, we proved that the intrinsic vulnerability is dynamic as a result of time-variations of some parameters. The elaborated vulnerability maps show variability in the spatial distribution of vulnerability degrees between the three years. The sensitivity analysis of changes in vulnerability towards changes in dynamic parameters showed that recharge is the key factor in the vulnerability variations in the irrigated area of this zone. The highly vulnerable areas of this aquifer have increased in relation to the increased volumes of irrigation water. Changes in effective weight between study years show that all the parameters of the DRASTIC method are necessary to assess vulnerability. The study of the temporal vulnerability variations, proposed in this paper, could constitute an approach allowing the determination of key factors in vulnerability dynamics. This can provide an important tool for the sustainable water resources management.
\end{abstract}

Keywords: Vulnerability; dynamic; DRASTIC; irrigation; Bou-Areg; Morocco.

\section{Introduction}

The intrinsic vulnerability characterizes the sensitivity of groundwater contamination. It is defined by geological and hydrogeological factors of aquifers [1], [2], [3]. In literature, several methods have been developed in order to assess the aquifers vulnerability to pollution. These methods are based on the following three approaches:

- Complex hydrogeological methods;

- Methods based on analogical relations and numerical modeling;

- Parametric models.

The founding concept as well as the various definitions of groundwater vulnerability to pollution can reveal a static definition of vulnerability, at least on the human time scale [4]. This consideration justifies the use of vulnerability maps for management and groundwater resources protection. However, some parameters taken into account in the vulnerability assessment are more or less variable in time and can consequently cause temporal variations in vulnerability. These variations can compromise the use of these maps as a decisionmaking tool.

The vulnerability dynamics could be studied on the basis of comparisons between vulnerability maps elaborated for different years, which will highlight the key factors in the aquifer vulnerability variation [5], [6]. In this work, we propose to study this phenomenon through an application to the Bou-Areg aquifer (Northeastern Morocco). This area is characterized by intense agricultural activities, covering more than $62 \%$ of its total area [7]. This activity was enhanced by the irrigation system putting into service since 1971. The contribution of irrigation water from the Moulouya River, fueled by the middle Atlas sources, has led to significant changes in the chemical and isotopic composition of this groundwater. In fact, the study of stable isotopes of the water molecule has shown that this groundwater has an Atlasic origin, highlighting the importance of irrigation in this aquifer recharge. In addition, the isotopic composition of nitrate in this groundwater show very high levels mainly from agricultural sources [8].

\section{Methodology}

In order to verify the impact of changes related to climate and anthropogenic factors on the vulnerability of the Bou-Areg aquifer, we applied the DRASTIC method for the years 1969, 1995 and 2006. The choice of 1969 allows the vulnerability assessment which qualified this aquifer state before the irrigation network installation. The other two years are chosen in order to assess the effect of the great variation in irrigation water volumes $\left(\Delta \mathrm{V}=49,17 \mathrm{Mm}^{3}\right)$, which may lead to variations in the aquifer recharge. 
To take into account the highly developed agricultural activities on this plain, vulnerability maps were realized on the basis of two weighting systems of DRASTIC method: DRASTIC phyt $_{\text {and DRASTIC }}$ norm.

\subsection{Description Of The Drastic Method}

The DRASTIC method is based on a weighting and indexing system of parameters [9]. This method is used to evaluate the intrinsic vulnerability taking into consideration seven parameters: D: Depth to water, R: net Recharge; A: Aquifer nature; S: Soil type; T: land Slope (Topography); I: unsaturated zone Impact and C: hydraulic Conductivity. The weighted sum of the parameters rates allows DRASTIC index calculation, according to equation (1):

$$
I_{\text {DRASTIC }}=D_{\mathrm{r}} \cdot D_{\mathrm{w}}+R_{\mathrm{r}} \cdot \mathrm{R}_{\mathrm{w}}+\mathrm{A}_{\mathrm{r}} \cdot \mathrm{A}_{\mathrm{w}}+\mathrm{S}_{\mathrm{r}} \cdot \mathrm{S}_{\mathrm{w}}+\mathrm{T}_{\mathrm{r}} \cdot \mathrm{T}_{\mathrm{w}}+\mathrm{I}_{\mathrm{r}} \cdot \mathrm{I}_{\mathrm{w}}+\mathrm{C}_{\mathrm{r}} \cdot \mathrm{C}_{\mathrm{w}}
$$

Where D, R, A, S, T, I, C, are the above parameters; r, w: rate and weight of each parameter.

The weights are variable depending on the relative importance of the parameters. This method suggests two weighting schemes based on land use: normal occupation or occupation by intensive agricultural activity [10] (Table 1).

Table 1: Weighting factors of the DRASTIC method parameters

\begin{tabular}{|c|c|c|}
\hline \multirow{2}{*}{ Parameter } & \multicolumn{2}{|c|}{ Weighting factors } \\
\hline & DRASTIC $_{\text {norm }}$ & DRASTIC $_{\text {phyt }}$ \\
\hline Depth to water (D) & 5 & 5 \\
\hline Unsaturated zone Impact (I) & 5 & 4 \\
\hline Recharge (R) & 4 & 4 \\
\hline Aquifer nature $(\mathrm{A})$ & 3 & 3 \\
\hline Hydraulic conductivity (C) & 3 & 3 \\
\hline Soil type (S) & 2 & 5 \\
\hline Topography $(\mathrm{T})$ & 1 & 3 \\
\hline
\end{tabular}

The vulnerability degree is assessed on the basis of the DRASTIC index classes. The vulnerability is even more important than the calculated index is high.

\subsection{Sensitivity Analysis Of The Drastic Method}

Sensitivity analysis of the DRASTIC method evaluates the influence of rating and weighting systems of each parameter on the vulnerability index. The objective of this analysis process is to identify the most important parameters of the model, prompting special attention which should be paid in their evaluation. To this effect, two sensitivity analysis methods were used: the map removal sensitivity analysis [11] and the Single-parameter sensitivity analysis [12].

The first test measures the sensitivity of the vulnerability map by removing one or more parameters. In this work we have adapted this test in the case of dynamic vulnerability. This adaptation is based on the relation (2) between the variation in the DRASTIC index and that of the parameters for a given period:

$$
\Delta \mathrm{IV}=\sum \Delta \mathrm{P}_{\mathrm{r}} \times \mathrm{P}_{\mathrm{W}}
$$

Where: $\Delta$ VI: vulnerability index variation; Pr, PW: rate and weight of parameter.

By applying this relation on aquifer vulnerability maps, evaluated for two different years, the sensitivity analysis could be used according to equation (3):

$$
\mathrm{Sa}_{\mathrm{d}}=\left|\frac{\left(\frac{\Delta \mathrm{IV}}{\mathrm{N}}-\frac{\Delta \mathrm{IV}^{\prime}}{\mathrm{n}}\right)}{\Delta \mathrm{IV}}\right| \times 100
$$

Where: $\mathrm{Sa}_{\mathrm{d}}$ : dynamic sensitivity index; IV: vulnerability index; IV': Modified vulnerability index; N: number of parameters used to calculate IV; n: number of parameters used to calculate IV'. This analysis will be performed only on areas of variable vulnerability $(\Delta \mathrm{IV} \neq 0)$.

\subsection{Site Description}

\section{Application on the Bou-Areg aquifer}

The Bou-Areg coastal plain is located on the Mediterranean coast in north-eastern Morocco (Fig. 1). This alluvial plain, of approximately $190 \mathrm{~km}^{2}$, is limited to the North-West by the Gourougou volcanic massif, the Beni Bou Ifrour massif to the West and the Kebdana relief to the South-East. In the South, the plain is connected to the Gareb plain through the Selouane corridor, while the northern border corresponds to the lagoon 
of Nador. The hydrographic network is constituted by temporary wadis, some of which serve as receptors of wastewater from upstream urban areas and a permanent river (Wadi Selouane).

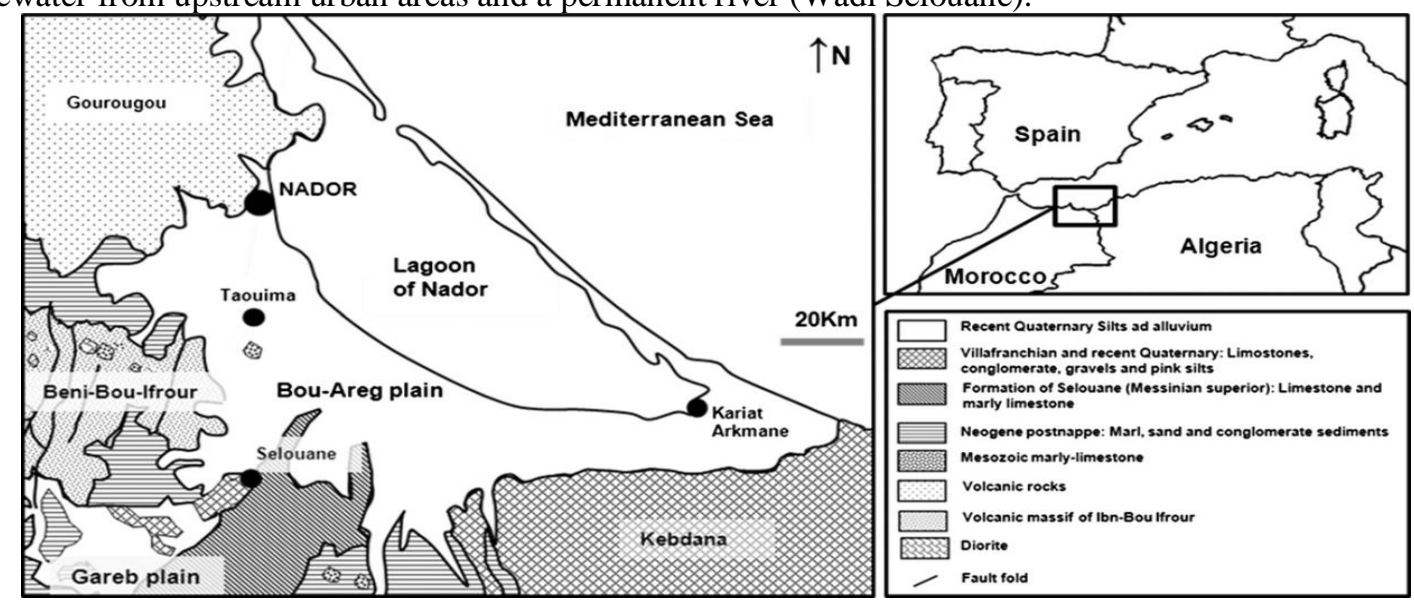

Figure 1. Geological map of the plain of Bou-areg (modified after [13]).

The Bou-Areg aquifer is composed by late-Pliocene-early-Quaternary deposits. It consists of four main formations with similar hydrological behavior [14]:

- Superficial formation composed by silts, clayey silts, encrusted limestone and marl-calcareous tufa that may contain gravels. This formation is characterized by a hydraulic conductivity of about $10^{-5} \mathrm{~m} \cdot \mathrm{s}^{-1}$;

- Within the first unit are intercalated formations of pebbles, gravels of volcanic or sedimentary origin, and sands. The hydraulic conductivity of this layer is about $10^{-4} \mathrm{~m} \cdot \mathrm{s}^{-1}$;

- The impervious bed of this aquifer is constituted by clays and Pliocene marls containing gypsum.

The Bou-Areg irrigated area, of about 10800 ha, was put into service since 1971. The annual volumes of irrigation water, consumed from the Machraa Homadi dam, are highly variable from one year to another $\left(64,45 \mathrm{Mm}^{3}\right.$ in 2000 and $15,26 \mathrm{Mm}^{3}$ in 2006 ; ORMVAM).

\subsection{Parameter Mapping}

Drastic parameter mapping were elaborated on the basis of data provided by the Agency of the Moulouya hydraulic basin and the Regional Office of Agricultural Development of Moulouya (Morocco).

Parameters, related to soil and topography, are not variable and are thereby considered static. In this area, the fluctuations in the groundwater static level are low under the effect of the lagoon static level which constitutes a limit of imposed potential. Therefore, the parameters related to the aquifer nature, unsaturated zone impact and the hydraulic conductivity of the aquifer do not show significant changes during the period chosen for the study.

\subsubsection{Static parameters}

\section{- $\quad$ Soil type (S)}

The soil type map was established by digitizing the Bou-Areg soil map completed by the unsaturated zone facies. The study area soil is characterized by dominance of clayey silt and calcareous silt respectively occupying $54.6 \%$ and $40.3 \%$ of the study area. Alluvial soils cover 5.1\% (Fig. 2.a).

\section{- Topography (T)}

The slope map was generated based on the Bouareg plain DEM. The slope varies between 0 and 79.1\%. The low slopes of less than $7 \%$ occupy the major part with more than $70 \%$ of this zone (Fig. 2.b). 

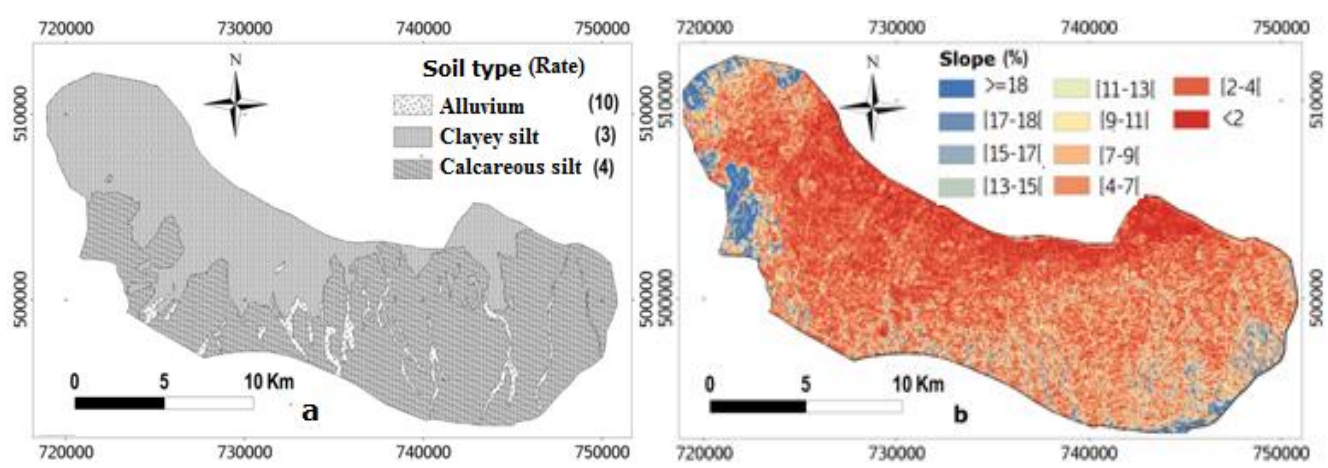

Figure 2. Maps of the Bou-Areg plain: a. soil type (S); b. land slope (T).

- Vadose zone impact (I) and aquifer nature (A)

These maps were elaborated on the basis of stratigraphic logs from 27 boreholes catching this groundwater. The facies of the unsaturated zone (fig. 3.a) consist of:

Clay, clayey silt and calcareous silt in the center and East;

- Alluvium, silty gravel and limestone-conglomerates in the North-West and a South-central part of the plain;

- Marl and gravel over a part to the North-West and all-along Afelioun Wadi in the East.

The dominant facies of the saturated zone (fig. 3.b) of this aquifer permit to distinguish:

- The conglomerates, gravels and pebbles in the North-West of the plain and all-along Afelioun Wadi in the East;

- Clayey or calcareous silt in the center and East;

- The gravelly or sandy silt and marl on two small areas in the East.

\section{- Hydraulic Conductivity (C)}

Hydraulic conductivity map (Fig. 3.c) was elaborated by interpolating the values calculated on the basis of test pumping in 24 boreholes distributed over the plain [15]. The hydraulic conductivity values of this aquifer range between $6,2.10^{-3}$ (IRE 2527/6 to the West) and 9,8.10-6 (IRE 1029/6 in the South-central). The high values are located in the North-West at the downstream part of the Gourougou stratovolcano. The low values are in the South-central part and the downstream of the Kebdana Mountain.

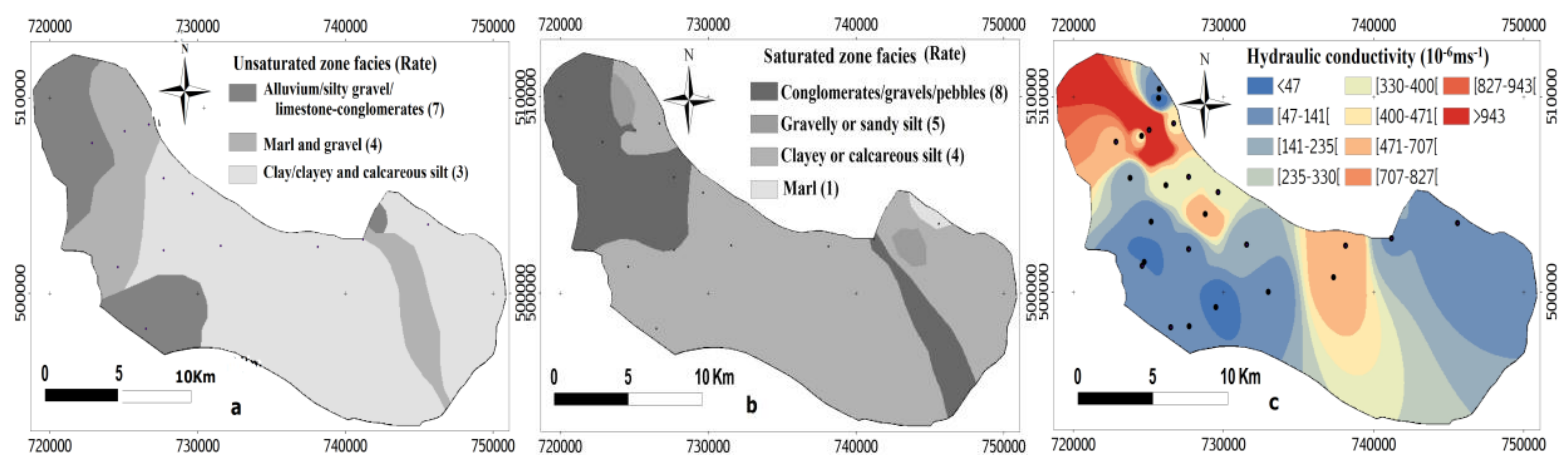

Figure 3. Maps of the Bou-Areg aquifer: a. unsaturated zone impact (I);

b. aquifer nature $(\mathrm{A})$; c. hydraulic conductivity $(\mathrm{C})$.

\subsubsection{Dynamic Parameters}

For the both time dependent parameters, groundwater depth and recharge, we studied their variations between the three chosen years: 1969, 2000 and 2006.

\section{- Groundwater depth (D)}

The depth maps of 2000 and 2006 have been established on the basis of 44 boreholes data (ABHM and ORMVAM). As for the 1969 map, it was digitized from the isobaths map at the scale 1/50000 [16].

The three maps of groundwater depth show an average increase in the groundwater level in the order of $2.5 \mathrm{~m}$ between 1969 and 2000 and $1.8 \mathrm{~m}$ between 2000 and 2006 (Fig. 4). 


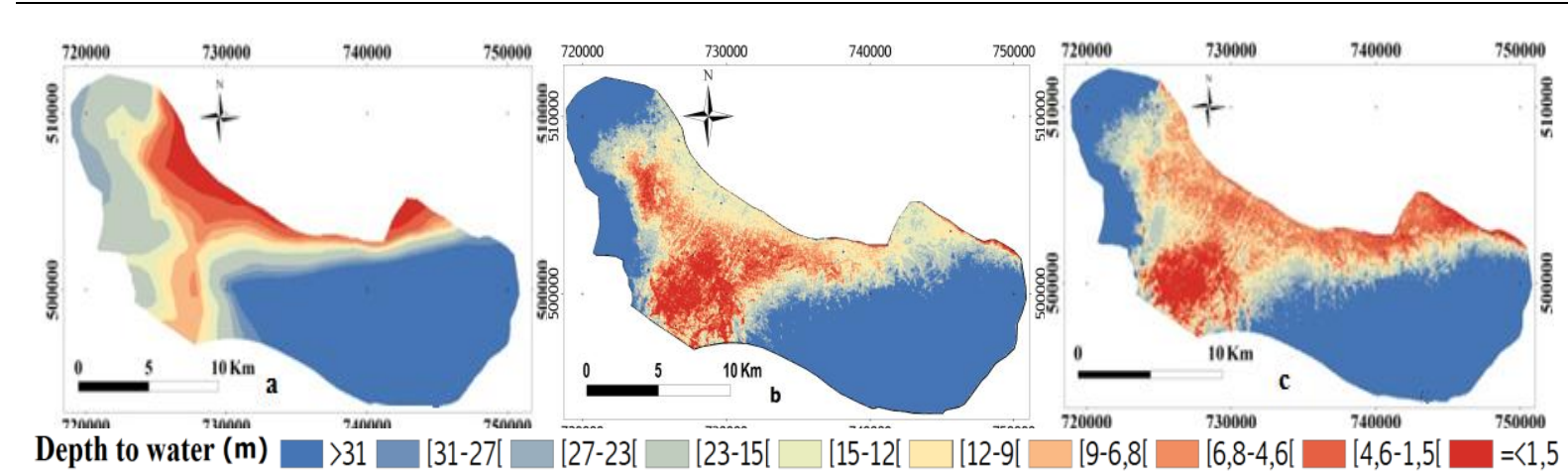

Figure 4. Maps of the Bou-Areg groundwater depths of the years: a.1969 b.2000 c.2006

The shallow depths are located at the central zone and marine borders to the north of the plain. The depth variations concern $59.3 \%$ and $42.7 \%$ of the study area respectively for the periods 1969-2000 and 20002006. These variations mainly concern the central part of the plain (irrigated district) and the shore zone of the Nador lagoon.

\section{- $\quad$ Recharge (R)}

Effective infiltration was calculated by the Thornthwaite method taking into consideration the EAW calculated for each soil type on the basis of unit values according to soil texture [17]. In irrigated areas, irrigation water is treated in the same way as rainwater. Table 2 shows the recharge values according to the soil types in irrigated and non irrigated zones.

For 1969 and 2006, recharge takes place only in alluvial soil characterizing the wadi beds. In 2000, the great volumes of irrigation water consumed have increased groundwater recharge in the irrigated area.

The variations in this parameter concern $37.8 \%$ and $41.5 \%$ of this zone for the periods of 1969-2000 and 2000-2006 respectively. They cover the wadi alluvial beds and the irrigated perimeter (Fig. 5).

Table 2: Bou-Areg aquifer recharge (IZ and NIZ: irrigated and non irrigated areas).

\begin{tabular}{|c|c|c|c|c|c|c|c|}
\hline \multirow{2}{*}{ Years } & \multirow{2}{*}{$\begin{array}{l}\text { Precipitation } \\
\quad(\mathbf{m m})\end{array}$} & \multirow{2}{*}{$\begin{array}{l}\text { Irrigation } \\
(\mathbf{m m})\end{array}$} & \multirow{2}{*}{ Soil type } & \multicolumn{2}{|c|}{ ETa (mm) } & \multicolumn{2}{|c|}{ Infiltration (mm) } \\
\hline & & & & NIZ & IZ & NIZ & IZ \\
\hline \multirow{3}{*}{$05-06$} & \multirow{3}{*}{308.00} & \multirow{3}{*}{141.10} & clayey silt & \multirow{3}{*}{236.46} & \multirow{3}{*}{338.63} & 0.00 & 0.00 \\
\hline & & & calcareous silt & & & 0.00 & 0.00 \\
\hline & & & alluvium & & & 81.00 & 154.39 \\
\hline \multirow{3}{*}{ 99-00 } & \multirow{3}{*}{183.10} & \multirow{3}{*}{633.00} & clayey silt & \multirow{3}{*}{151.53} & \multirow{3}{*}{628.80} & 0.00 & 122.35 \\
\hline & & & calcareous silt & & & 0.00 & 127.35 \\
\hline & & & alluvium & & & 11.57 & 177.35 \\
\hline \multirow{3}{*}{$68-69$} & \multirow{3}{*}{262.00} & \multirow{3}{*}{ Not in service } & clayey silt & \multirow{3}{*}{\multicolumn{2}{|c|}{201.60}} & \multicolumn{2}{|c|}{0.00} \\
\hline & & & calcareous silt & & & \multirow{2}{*}{\multicolumn{2}{|c|}{$\frac{0.39}{50.39}$}} \\
\hline & & & alluvium & & & & \\
\hline
\end{tabular}

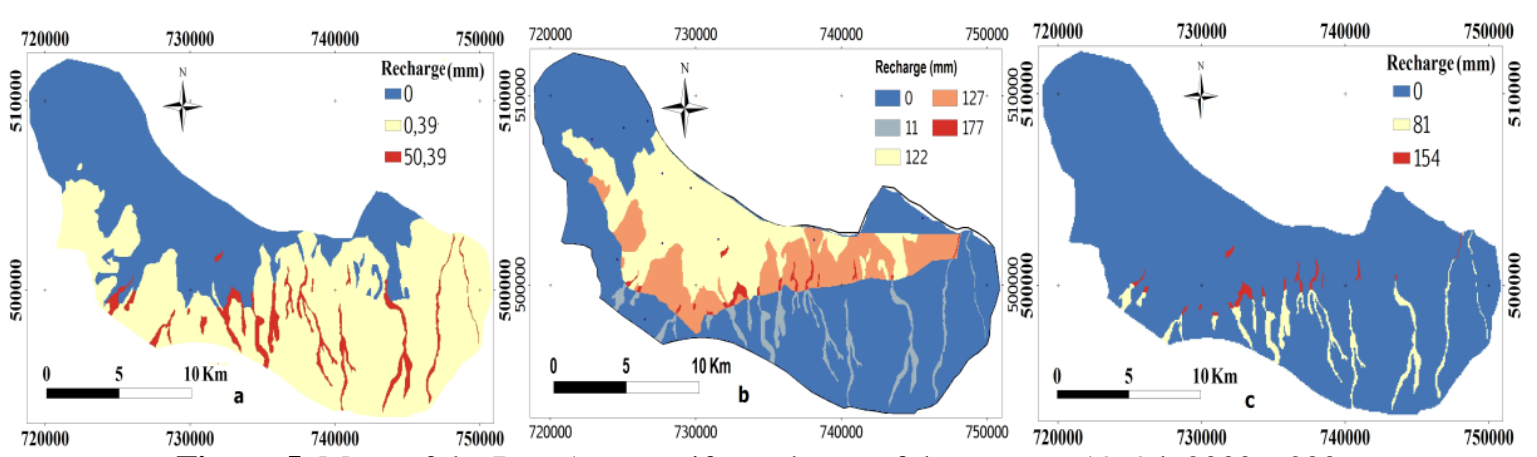

Figure 5. Maps of the Bou-Areg aquifer recharge of the years: a.1969 b.2000 c.2006

\subsection{Vulnerability Maps Study}

The DRASTIC phyt $_{\text {and DRASTIC }}$ norm vulnerability maps of the three study years show a different spatial distribution of vulnerability degrees from one year to another.

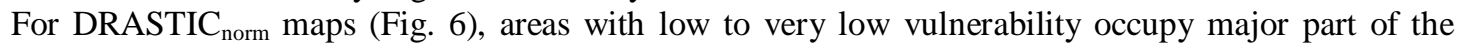
Bou-Areg plain with $64.38 \%, 49.93 \%$ and $54.37 \%$ respectively for 1969, 2000 and 2006. They cover mainly the East and South-East parts of the plain. 
The areas highly vulnerable have expanded going from $8.81 \%$ to $13.06 \%$ between 1969 and 2000 . These areas have then, decreased between 2000 and 2006, covering only $4.86 \%$ in small western and Southcentral areas. However, they occupy the central part on the map of 2000 in irrigated area.

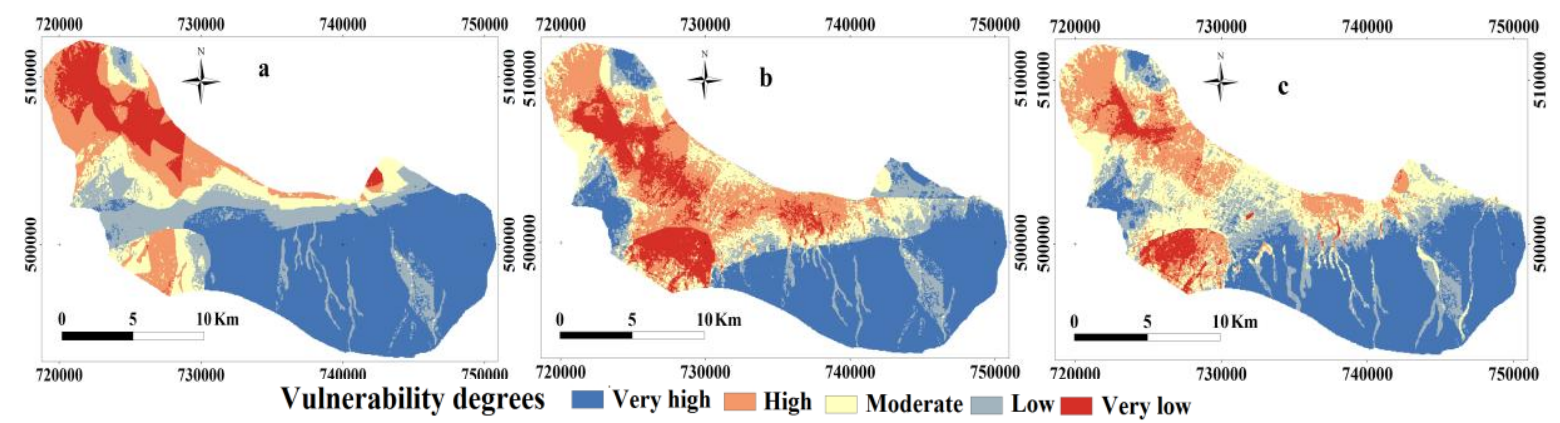

Figure 6. DRASTIC ${ }_{\text {norm }}$ maps of the Bou-Areg aquifer of the years: a.1969 b.2000 c.2006

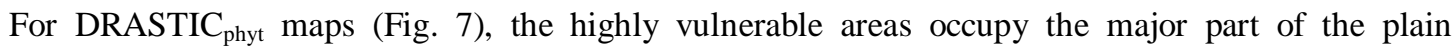
compared to other vulnerability degrees. These areas have increased going from $30.05 \%$ to $43.98 \%$ between 1969 and 2000. They were then, decreased in 2006 to occupy only $37.61 \%$ of this plain. They cover the western part of the plain, wadi beds and a small lagoon shore-band on the 1969 map. However, they occupy the central part (irrigated area) and wadi beds on 2000 and 2006 maps. For low to very low vulnerability areas, they cover mainly the East and Southeast of the plain, with 28.6\%, 22.9\% and 23.2\% respectively for 1969, 2000 and 2006.

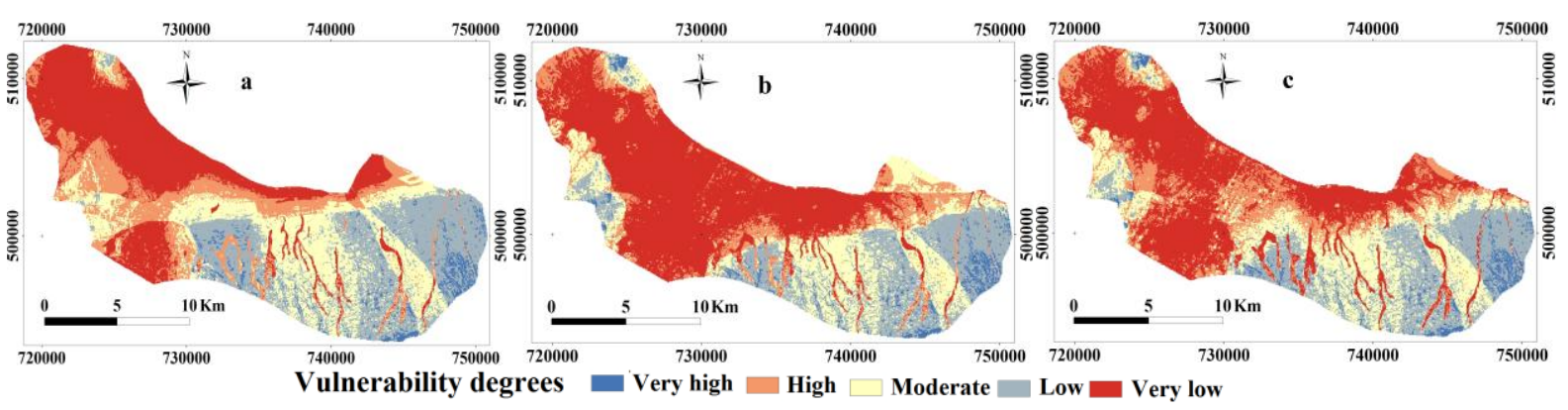

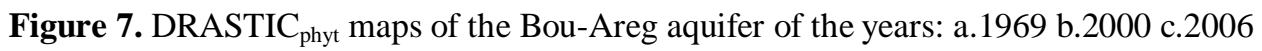

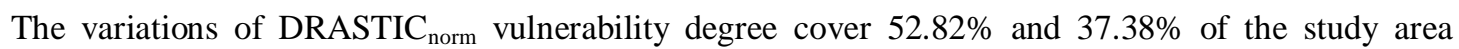
respectively for 1969-2000 and 2000-2006 periods. About the vulnerability assessed by DRASTIC phyt $_{\text {, these }}$ variations concern $38.43 \%$ and $25.80 \%$ of the study area respectively for $1969-2000$ and 2000-2006 periods.

\subsubsection{Sensitivity analysis}

\section{- Single-parameter sensitivity analysis}

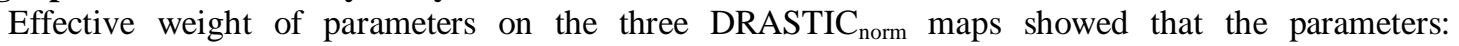
unsaturated zone impact, depth to water, and Aquifer nature are the most influential parameters on vulnerability.

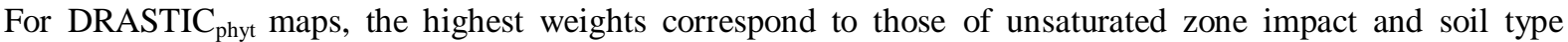
parameters (tab. 3).

Table 3: Effective weight of DRASTIC parameters

\begin{tabular}{|c|c|c|c|c|c|c|}
\hline & \multicolumn{3}{|c|}{ DRASTIC $_{\text {norm }}$} & \multicolumn{3}{c|}{ DRASTIC $_{\text {phyt }}$} \\
\hline Parameter & $\mathbf{1 9 6 9}$ & $\mathbf{2 0 0 0}$ & $\mathbf{2 0 0 6}$ & $\mathbf{1 9 6 9}$ & $\mathbf{2 0 0 0}$ & $\mathbf{2 0 0 6}$ \\
\hline D & 19.03 & 18.18 & 21.00 & 15.17 & 14.65 & 16.72 \\
\hline R & 5.08 & 10.32 & 5.42 & 3.88 & 8.23 & 4.15 \\
\hline A & 18.33 & 17.33 & 17.91 & 14.20 & 13.64 & 14.04 \\
\hline S & 10.10 & 9.42 & 9.61 & 18.95 & 18.00 & 18.36 \\
\hline T & 9.72 & 8.93 & 9.24 & 22.06 & 20.65 & 21.29 \\
\hline I & 23.29 & 21.94 & 22.57 & 14.49 & 13.87 & 14.23 \\
\hline C & 14.45 & 13.87 & 14.24 & 11.24 & 10.95 & 11.20 \\
\hline
\end{tabular}


This sensitivity analysis shows that the relative effects of the seven parameters on the vulnerability index are more or less variable from one year to another. The great variation amplitudes correspond to the recharge and depth parameters. This result highlights the importance of all the parameters of the DRASTIC method in assessing vulnerability.

\section{- Sensitivity Analysis Of The Vulnerability Dynamic}

Sensitivity analysis of vulnerability variations to parameters dynamic between the three years was performed on the irrigated area in order to evaluate the recharge effect of irrigation return flow. The results of both DRASTIC phyt $_{\text {and }}$ DRASTIC ${ }_{\text {norm }}$ vulnerability maps are similar, as a result of the same depth and recharge weighting in these two methods (Tab. 4).

Table 4: Sensitivity Analysis Of The DRASTIC Maps Dynamic

\begin{tabular}{|c|c|c|c|}
\hline Periods & $\Delta$ Parameters & Irrigated Zone & All the plain \\
\hline \multirow{2}{*}{ 1969-2000 } & $\Delta \mathbf{D}$ & 0.23 & 0.21 \\
\cline { 2 - 4 } & $\boldsymbol{\Delta} \mathbf{R}$ & 0.26 & 0.16 \\
\hline \multirow{2}{*}{$\mathbf{2 0 0 0 - 2 0 0 6}$} & $\boldsymbol{\Delta} \mathbf{D}$ & 0.28 & 0.23 \\
\cline { 2 - 4 } & $\boldsymbol{\Delta} \mathbf{R}$ & 0.40 & 0.29 \\
\hline
\end{tabular}

The vulnerability variation between 1969 and 2000 is more sensitive to depth parameter (D) with respect to the recharge parameter $(\mathrm{R})$. In fact, the groundwater depth variation in this period, with an average of $2.5 \mathrm{~m}$, covers a large part of the plain (59.3\%). However, the recharge variation is negligible over the major part (62.2\%). Between 2000 and 2006 the recharge variations become more influential as a result of low variation in the groundwater depth fluctuation, with an average of $1.8 \mathrm{~m}$, covering only $42.7 \%$.

The sensitivity analysis of the vulnerability dynamics performed on the irrigated area shows that the recharge variations (R) are the most influential for the two study periods. This result highlights the effect of irrigation on the vulnerability of the aquifer.

\section{Conclusion}

In this work we studied the dynamic aspect of vulnerability under the effect of climatic and anthropogenic factors. The application was made on the Bou-Areg aquifer which has undergone major modifications as a result of agricultural development. The vulnerability maps of this aquifer were elaborated by the DRASTIC method for 1969, 2000 and 2006. The last two years have been chosen to allow monitoring of variations in the vulnerability depending on the volume of irrigation water. The year 1969 reflects the state of the aquifer before installation of the irrigation system. The comparative study of resulting maps show variability in the spatial distribution of vulnerability degrees.

In the stemming from this application, we have shown that the intrinsic vulnerability is time-varying. In this aquifer the vulnerability variations depend on fluctuations in the depth to water and recharge related to the returns of irrigation. In fact, the sensitivity analysis of the vulnerability variations showed high sensitivity to the recharge variations on the irrigated area. The comparison of the respective areas of different vulnerability degrees shows that 2000 correspond to an expansion of the highly vulnerable areas, occupying the irrigated zone, according to a very important irrigation return flow. This last factor is therefore the key to control the vulnerability of this aquifer through the rational irrigation.

The temporal variability of vulnerability highlighted in this study could compromise the use of vulnerability maps in water resources protection. However, statistical study of these variations allows the determination of key factors in vulnerability dynamics providing an important guidance tool for water resources management.

\section{Acknowledgements}

This work was done in collaboration with the Water Basin Agency of Moulouya (ABHM) OujdaMorocco and the Regional Office of Agricultural Development of Moulouya (ORMVAM) Bérkane-Morocco.

\section{References}

[1]. D. Daly, A. Dassaargues, D. Drew, S. Dunne, N. Goldscheeider, S. Neale, I.C. Popescu and F. Zwahlen, Main concepts of the European approach for (karst) groundwater vulnerability assessment and mapping, Hydrogeology Journal, vol.10, 2002, 340-345.

[2]. J. Vrba and A. Zaporozec, Guidebook on mapping groundwater vulnerability, IAH, Vol. 1,131p, 1994.

[3]. R.C. Gogu and A. Dassargues, Current trends and future challenges in groundwater vulnerability assessment using overlay and index methods, Environnement Geology, 39(6), 2000, 549-59.

[4]. J. Vrba, Hydrogeological aspects of groundwater protection and pollution. In Criteria for and Approaches to Water Quality management in Developing Countries, Natural Resources Water Series no. 26, United Nations, New York, 1991

[5]. M. Amharref, R. Bouchnan, A. S. Bernoussi, Extension of DRASTIC approach for dynamic vulnerability assessment in fissured area: Application to the Angad aquifer (Morocco), in : B. Andreo et al. (Ed.), Hydrogeological and Environmental Investigations in Karst Systems, Environmental Earth Sciences 1. (Springer-Verlag Berlin Heidelberg, 2015) 407-414. 
[6]. H.E. Saouini, M. Amharref and A.S. Bernoussi, Vulnérabilité à La Pollution des Eaux Souterraines: Statique ou Dynamique? Application à la Nappe de R'Mel (Maroc). International Journal of Innovation and Applied Studies, Vol. 6 No. 4, 2014, 929-940.

[7]. El Yaouti, A. El Mandour, D. Khattach, O. Kaufmann, Modelling groundwater flow and advective contaminant transport in the Bou-Areg unconfined aquifer (NE Morocco), J. Hydro-Environ. Res. 2, 2008, 192-209.

[8]. Re, E. Sacchi, J. L. Martin-Bordes, A. Aureli, N. El Hamouti, R. Bouchnan and G. M. Zuppi, Processes affecting groundwater quality in arid zones : The case of the Bou-Areg coastal aquifer (North Morocco), Appl. Geochem. 34, 2013, $181-198$.

[9]. L. Aller, T. Bennet, J.H. Lehr, R. Petty and G. Hackett, DRASTIC: Standardized system to evaluate ground water pollution potential using hydrogeologic settings, (U.S Epa-600/2-87-035, 1987).

[10]. Lallemand-Barres, Normalisation des critères d'établissement des cartes de vulnérabilité aux pollutions. Étude documentaire préliminaire, (Rapport BRGM, 1994).

[11]. W. A. Lodwick, W. Monson and L. Svoboda, Attribute error and sensitivity analysis of map operations in geographical information systems: suitability analysis, International Journal Of Geographical Information Systems, 4(4), 1990, 413-428.

[12]. P. Napolitano and A.G. Fabbri, Single-parameter sensitivity analysis for aquifer vulnerability assessment DRASTIC and SINT ACS, IAHS Publications-Series of Proceedings and Reports-Intern Assoc Hydrological Sciences, No. 235, 1996, $559-566$.

[13]. F. El Yaouti, A. El Mandour, D. Khattach, J. Benavente, and O. Kaufmann, Salinization processes in the unconfined aquifer of BouAreg (NE Morocco): a geostatistical, geochemical, and tomographic study, Appl. Geochem, 24, 2009, 16-31.

[14]. Chaouni Alia, N. El. Halimi, K. Walraevens, E. Beeuwsaert and W. De Breuck, Investigation de la salinisation de la plaine de BouAreg (Maroc nord-oriental), in Freshwater Contamination: Proceedings of an International Symposium Held During the Fifth Scientific Assembly of the International Association of Hydrological Sciences (IAHS), Vol. 243, Rabat, Morocco, 1997, 211-220.

[15]. Chaouni Alia, Etude hydrogéologique et hydrochimique de la plaine côtière de Bou-Areg (Maroc Nord-Oriental), doctoral diss., Faculté de Wetensvhappen, Université de Gent. Bélgique. 2001.

[16]. Ph. Carlier, Plaine du Bou-Areg - Région de Nador - Cartes de la nappe phréatique avec notices explicative. (Ministère des Travaux Publics et des Communications - DH/DRE, Centre régional de Berkane, 1969).

[17]. D. Baize et B. Jabiol, Guide pour la description des sols, (Editions Quae, 1995) 